\title{
No Fair Play for Millionaires? McCain-Feingold's Wealthy Candidate Restrictions and the First Amendment
}

\author{
Richard Wolf Hess $\dagger$
}

In 2002, Congress passed and President George W. Bush signed the first comprehensive changes to federal campaign finance law since 1974. The new law, the Bipartisan Campaign Reform Act of 2002 (BCRA), better known as McCain-Feingold, included a provision to deal with the so-called Millionaire Loophole, which allows wealthy candidates to spend unlimited personal funds on their own campaigns, without regard for contribution restrictions or voluntary spending limits. $^{2}$

BCRA's "Millionaire Provision" represents a new attempt to solve an old dilemma. Over thirty years ago, the Federal Election Campaign Act of 1971 (FECA) ${ }^{3}$ attempted to address the same problem: candidates willing to spend their own money liberally to ensure victory. FECA prohibited candidates from spending personal funds in excess of statutory limits. ${ }^{4}$ This prohibition, however, did not survive the Supreme Court's seminal campaign finance decision, Buckley $v$ Valeo, which held that restrictions on campaign spending violated the First Amendment. ${ }^{6}$

The Supreme Court's decision in Buckley governs all aspects of federal elections, including a self-funded candidate's right to spend her own funds in pursuit of federal office. By invalidating limits on selffunding while generally upholding contribution limits, Buckley created

$\dagger$ B.A. 1995, Emory University; J.D. Candidate 2004, The University of Chicago.

1 See Bipartisan Campaign Reform Act of 2002, Pub L No 107-155, 116 Stat 81, to be codified at 2 USC $\$ 431$ et seq. See also Elisabeth Bumiller and Philip Shenon, President Signs Bill on Campaign Gifts: Begins Money Tour, NY Times A1 (Mar 28, 2002).

2 See BCRA $\$ 304$ (providing for increased contribution limits and relaxed party spending restrictions for the opponents of self-funded candidates).

3 Pub L No 92-255, 86 Stat 3, codified as amended at 2 USC $\$ \$ 431-56$ (2000).

4 See FECA $\S 203,18$ USC $\S 608(a)(1)$ (Supp 1975), repealed by the Federal Election Campaign Act Amendments of $1976 \S 201$, Pub L No 94-283, 90 Stat 476, 496. The personal funds limits varied by the office sought. Presidential candidates could spend $\$ 50,000$. Senate candidates, and House candidates from states permitted only one representative, could spend $\$ 35,000$, and all other House candidates could spend a maximum of $\$ 25,000$.

5424 US 1 (1976).

6 See id at 39-59 (holding that FECA and its 1974 Amendments unconstitutionally limited the amount individual candidates may spend on their own campaigns). 
an opening for candidates to spend unlimited campaign funds, as long as those funds belong to the candidate personally or her family.'

To close this loophole, legislators included in the McCainFeingold legislation a "Millionaire Amendment." As passed, the Millionaire Provision allows opponents of self-funded candidates to raise campaign funds in amounts exceeding the statutory contribution limits that would otherwise apply. By raising contribution limits for selffinanced candidates' opponents, the new law attempts to discourage what Buckley prohibits the government from limiting directly: wealthy individual candidates funding their own campaigns.

A potential constitutional problem arises in attempting to fit the new law into the Buckley framework..$^{10}$ Since campaign finance laws concern political expression, a subject at the core of First Amendment speech and association protections, any restrictions must be strictly scrutinized for whether they meet a compelling government interest." Buckley itself identified only one such interest-reducing the appearance of corruption. The Court reasoned that limiting the dollar amount a candidate may accept from any given contributor achieves

7 See Jonathan D. Salant, Millionaires in Congress Bring Potential Conflicts, Milwaukee J Sentinel 17A (Jan 5, 2003) (indicating "[c]lose to half" of the incoming members of the 108th Congress are millionaires); Amy Keller, The Roll Call 50 Richest: For Richer or Poorer: Thanks to Spouses, Kerry Keeps Top Spot and Clinton Joins List, Roll Call (Sept 9,2002) (identifying the 50 wealthiest members of Congress and noting that at least 170 members are millionaires).

8 See BCRA $\$ 304$. This section contains the bulk of the changes affecting wealthy candidates. Related elements can be found in $\S 319$ (House members) and $\S 316$ (available funds formula for determining applicable spending thresholds). For examples of BCRA's more sweeping and conspicuous provisions, see $\S 101$ (banning national party committees from raising, spending, or soliciting unregulated non-federal donations or "soft money"); $\$$ 201-04 (redefining "electioneering communication" and banning such communications within sixty days of an election). These new restrictions "have been [among the] most frequently challenged by BCRA's opponents ...." Joseph E. Sandler and Neil P. Reiff, Bipartisan Campaign Reform Act of 2002: Law and Explanation 24 (CCH Chicago 2002).

9 See BCRA $\$ 307$ (setting individual contribution limits to candidates, notwithstanding Millionaire Provision adjustments, at $\$ 2,000$ and indexing limit to inflation).

10 Various plaintiffs, over forty in number and ranging from the Republican National Committee to the California Democratic Party, challenged BCRA before a special three-judge panel of the U.S. District Court for the District of Columbia. See Sandler and Reiff, Bipartisan Campaign Reform Act of 2002 at 26 (cited in note 8). The McConnell plaintiffs (led by Senator Mitch McConnell and authorized by BCRA) challenged the Millionaire Provision as, among other things, infringing wealthy candidates' and contributors' First Amendment rights. Second Amended Complaint for Declaratory and Injunctive Relief, McConnell v FEC, No 02-0582 (RJL), Count VIII at *42-43 (D DC filed May 7, 2002), online at http://www.law.stanford.edu/ library/campaignfinance/mcconnell-v-feccomplaint50702.pdf (visited May 8, 2003). In a May 1, 2003 decision, the panel unanimously declined to reach the question of the constitutionality of the Millionaire Provision, finding that "this Court lacks standing to entertain challenges to this provision." McConnell v FEC, No 02-0582, slip op at 11 (D DC May 1,2003).

11 See Buckley, 424 US at 44-45 ("[T] he constitutionality of [campaign expenditure limits] turns on whether the governmental interests advanced in its support satisfy the exacting scrutiny applicable to limitations on core First Amendment rights of political expression."). 
this interest. ${ }^{12}$ In the case of a self-funded candidate, it is not obvious that this justification applies at all. After all, who is less likely to be corrupted by donations than the candidate who need not accept any? Further, if restricting the size of contributions to candidates reduces corruption, why are those restrictions less essential simply because one's opponent chooses to spend her own money?

As for other permissible compelling interests, Buckley squarely rejected one of them: that the government may level the playing field between candidates of diverse means. In particular, the Court denied that the government's "interest in equalizing the financial resources of candidates competing for federal office" could justify "restricting the scope of federal election campaigns." ${ }^{\prime 3}$ The Millionaire Provision-by raising the contribution limit for opponents of wealthy candidatesattempts to equalize candidates' ability to compete.

In this Comment, I address these issues by examining the constitutionality of McCain-Feingold's Millionaire Provision, specifically, the potential for a constitutional challenge based on the wealthy candidate's First Amendment rights. I introduce the new law in Part I, including its complex formula for determining when a wealthy candidate triggers the Millionaire Provision and what benefits accrue to her opponent. I also describe the different legislative accommodations that entered into this provision during the legislative debate, and conclude by examining the rationale for the Millionaire Provision as revealed in BCRA's legislative history.

Part II examines current campaign finance restrictions and their permissible rationales after Buckley. I compare the treatment of contributions and expenditures in the Buckley scheme and follow the Court's treatment of contribution limits since 1976. Additionally, I consider the relevant constitutional tests for campaign finance laws challenged under the First Amendment, and examine how courts have addressed several state campaign finance laws attacked on First Amendment grounds.

Finally, Part III outlines the First Amendment challenge to BCRA by examining two potential hurdles: (1) the free speech harm from the Millionaire Provision and (2) whether the law survives judicial scrutiny. I conclude that the new law does not harm free speech values and, alternatively, that traditional government interests in campaign finance regulation justify whatever harm the law inflicts.

12 See id at 26.

13 Id at 56. 


\section{BCRA'S MILLIONAIRE PROVISION}

At the start of congressional debate on the McCain-Feingold bill, Senator Pete Domenici introduced an amendment to raise contribution limits for candidates facing self-funded opponents. ${ }^{14}$ Many Democratic reformers opposed the Domenici Amendment, viewing it as a step backward for campaign finance reform. McCain-Feingold supporters argued that the amendment contradicted the stated goals of reform by increasing contribution limits and the overall amount of money in the political system. ${ }^{15}$ Nevertheless, after last-minute tweaking of its provisions and in exchange for a total ban on unlimited, nonfederal contributions, or soft money, these reform supporters ultimately accepted the Domenici Amendment's increase in limits. ${ }^{16}$

\section{A. Millionaire Threshold Formula and Opponent Benefits}

BCRA's Millionaire Provision employs a complex formula to determine the threshold spending amount for each candidate. If a selffunded candidate spends more than twice that amount, she "triggers" a provision that increases the contribution limits for her opponents. Once these provisions are triggered, a self-funded candidate's opponent may then raise contributions in greater and greater amounts, keyed to the level by which the self-funded candidate exceeds the threshold. In addition, for a wealthy candidate who exceeds the selffunding threshold limit by more than ten times, the new law removes the ordinary limits on political party contributions to her opponent's campaign."

For an illustration of the benefits that an opponent of a millionaire can receive, take a hypothetical U.S. Senate candidate from Illi-

14 See Amy Keller and Paul Kane, Unscripted Debate Wins High Praise, Roll Call 1, 24 (Mar 22, 2001). Reform advocates initially viewed the passage of the amendment, on a 70-30 vote, as a setback for McCain-Feingold as it suggested that the reformers' coalition might disintegrate as more loopholes for raising contribution limits emerged. See BCRA, S 27, 107th Cong, 1st Sess (Jan 22, 2001), in 147 Cong Rec S 2466 (Mar 19, 2001) (remarks of Senators Dodd and Reid).

15 See John Mercurio, Sharing the Wealth: Despite Vote to Punish Rich Candidates, Millionaires Still a Big Factor for Democrats, Roll Call 15 (Mar 22, 2001) (quoting remarks by Democratic senators opposing the amendment, and noting that both major parties' Senate campaign committees actively recruit wealthy candidates).

16 See Andrew Taylor and John Cochran, McCain-Feingold Tradeoffs Heighten Qualms within Coalition, 59 CQ Wk 647, 650-51 (2001) (discussing the passage of the Domenici Amendment).

17 See BCRA $\S 304(a)(2)$. In addition, BCRA $\S 304(b)$ establishes a reporting requirement to prevent candidates from dumping personal funds into a race shortly before Election Day. Within fifteen days of becoming a candidate, an individual must notify the Federal Election Commission and each candidate in the race of how much the candidate intends to spend from her personal funds in excess of the threshold amount. BCRA requires similar declarations once the candidate actually spends twice the threshold amount, and again at $\$ 10,000$ increments. 
nois. With a November 2000 voting-age population (VAP) of $8,859,000,{ }^{18}$ BCRA $\S 304(a)$ establishes a threshold amount of $\$ 504,360$, which is the state's VAP multiplied by $\$ .04$, plus $\$ 150,000$. Once the candidate announces her intention to spend twice this amount," or just over $\$ 1$ million, her opponent may then raise contributions of $\$ 6,000$ from any individual, ${ }^{20}$ three times the ordinarily applicable limit of $\$ 2,000$. If the self-funded candidate continues to spend personal funds and exceeds the threshold by four times the limit $(\$ 2,017,440)$, her opponent may then raise contributions of $\$ 12,000$ from any individual. ${ }^{21}$ These contribution limits are measured per election, not per year or cycle, so if the new limits applied to both a primary and a general election, the opponent could receive $\$ 24,000$ from one individual, six times the ordinary limit of $\$ 2,000$ per election.

If the self-funded candidate spends ten times the threshold limit in personal funds $(\$ 5,043,600)$, in addition to a $\$ 12,000$ contribution limit from any individual, the opponent's political party may spend additional funds to support its non-wealthy candidate. ${ }^{22}$ Under a provision unchanged by BCRA, normally, party limits allow a state or national party committee to spend the greater of $\$ 20,000$ or $\$ .02$ times the VAP. In Illinois, the limit would be just over $\$ 175,000$ in coordinated or independent party spending absent a wealthy opponent triggering the opponent benefit provisions. ${ }^{23}$

\section{B. Adjustments to the Millionaire Amendment}

The Millionaire Provision emerged from Congress containing several features, some quite complex, to address concerns regarding the law's application in a variety of situations. These attempts to finetune the Millionaire Provision are important for a few reasons. First, they reflect congressional concerns about the need to tailor the new law to avoid charges of unfairness toward challengers by taking into account their opponent's (presumably an incumbent's) fundraising success when determining whether to boost anyone's contribution limits. Additionally, the sophisticated nature of the legislative drafting in this area helps to rebut allegations of statutory bluntness; the new law takes into account numerous factors in determining whether to raise a

18 See US Census Bureau, Reported Voting and Registration of the Total Voting-Age Population, by Sex, Race, and Hispanic Origin, for States: November 2000, online at http:// www.census.gov/population/socdemo/voting/p20-542/tab04a.pdf (visited May 8, 2003).

19 As required by BCRA $\$ 304(\mathrm{~b})$.

20 See BCRA $\$ 304(a)$.

21 See id.

22 See id. Although the provisions contained in this section add some complexity, the law essentially limits additional party expenditures - combined with contributions raised under increased limits - to the amount of personal funds spent by the wealthy candidate.

23 See 2 USC $\$ 441 a(d)(3)(A)(2000)$. 
challenger's contribution limits. Three such factors include state-bystate proportionality, incumbent and reciprocal funding advantages, and caps on additional fundraising.

\section{Proportionality between states.}

The Millionaire Amendment as originally introduced merely contained fixed-dollar limits on the maximum a self-financed candidate could spend before her opponent received the benefit of increased contribution limits. ${ }^{24}$ If a self-financed candidate intended to spend $\$ 500,000$, the law would have tripled her opponent's contribution limits. Similarly staggered increases occurred for self-financed candidates spending $\$ 800,000$ and over $\$ 1$ million. ${ }^{25}$

On the first day of debate, senators criticized the fixed limits as insufficiently adapted to the varied cost of campaigning in different states. ${ }^{26}$ Differences in both television advertising costs and state populations meant that a wealthy candidate would spend different amounts depending on where the race took place. ${ }^{27}$ Unamended to reflect these geographical differences, the Senate voted down this first Millionaire Amendment $51-48 .^{28}$ Supporters acknowledged the shortcomings in the amendment's then-current form, and reintroduced it the next day with the voting age population formula described above. ${ }^{29}$

2. Opposition personal and available funds offset.

Other features of the Millionaire Amendment appear designed to mitigate fears that the measure had become an attempt to shield incumbent officeholders from competitive races. The "Opposition Personal Funds Amount," which is used to determine the threshold amount, first subtracts out any personal funds spent by the candidate seeking increased limits. ${ }^{30}$ Under this provision, no millionaire incum-

24 See BCRA, 147 Cong Rec at S 2450 (Mar 19, 2001).

25 See id.

26 See, for example, id at S 2455 (remarks of Senator McCain) (Such limits represent "a meat-ax approach to a problem that requires a scalpel.... This does not get at really the different aspects of a small state or a big state. If I had $\$ 1$ million, I could buy a lot of TV [advertising] in New Mexico. I cannot buy very much in California.").

27 A wealthy candidate in Wyoming, which has inexpensive television rates and few voters, could conduct a relatively cheap campaign and a wealthy candidate might never reach the threshold amount despite vastly outspending a non-wealthy opponent. California, by contrast, has both high campaign costs and a large population, so a wealthy candidate would exceed these set thresholds quickly.

28 See BCRA, 147 Cong Rec at S 2468 (Mar 19, 2001) (Rollcall Vote No 37). The vote broke down largely along party lines, with Democrats (and reformist Republicans) voting against the amendment and reform opponents (mostly Republicans) supporting it.

29 See id at S 2538 (Mar 20,2001) (remarks of Senator DeWine).

30 See BCRA \& 304(a)(2). 
bent senator may benefit from increased contribution limits when her opponent is also a wealthy candidate.

The Millionaire Provision also contains another offset, one that apparently recognizes that incumbent members of Congress can accumulate large war chests of campaign contributions and that the only way to ensure a competitive race may be to increase a challenger's willingness and ability to spend personal funds. The provision calculates the "Gross Receipts Advantage," which the law defines as the aggregate amount of half a candidate's fundraising total, determined on each of two days during the year before the election. ${ }^{31}$ Just as with the opposition personal funds amount, the candidate seeking increased contribution limits in response to a self-financing opponent must first subtract her gross receipts advantage, if any. Suppose the hypothetical Illinois senate candidate had managed to amass, through private fundraising, a million-dollar campaign fund in the year leading up to the campaign. The Millionaire Provision formula would include that "gross receipts advantage" when calculating whether the candidate could raise funds under higher limits.

3. Money raised under high limits subject to cap.

A final adjustment appearing in the Millionaire Provision prohibits a candidate from accepting contributions-or a party from spending on that candidate's behalf-when doing so would exceed the level of personal funds spent by the candidate's wealthy opponent by 110 percent. ${ }^{33}$ Thus, the Millionaire Provision creates a cap on the nonwealthy candidate's fundraising (achieved under elevated limits) and the party's spending that is tied to the amount her opponent spends to personally fund her campaign. As with other provisions, this appears to have been added to address reformers' concerns that the increased contribution limits moved campaign finance reform in the wrong direction by increasing, rather than decreasing, the amount of money spent on campaigns.

\section{Congressional Intent and the Millionaire Provision}

As noted above, although it permits some restrictions on political speech in a campaign, Buckley recognizes that spending limits may infringe First Amendment values; consequently such restrictions must be necessary to accomplish a compelling government interest. Buckley allowed contribution restrictions on an anti-corruption rationale, but rejected the argument that Congress may permissibly restrict cam-

\footnotetext{
31 See BCRA $\$ 316$.

32 See id.

33 See BCRA $\$ 304$.
} 
paign spending in order to equalize different candidates' ability to compete. In the Senate's debate over BCRA, however, advocates of the Millionaire Provision pointed to the new law as both an anticorruption measure and a way to level the playing field.

1. Leveling the playing field.

During Senate deliberations, supporters of the Millionaire Amendment candidly described what motivated their legislative attempts. The Senate bill's main sponsor, Senator Domenici, stated, "We're trying to ensure that the person running against a wealthy candidate gets a fair shake." Domenici later added, "By enacting this common sense provision, the playing field will be leveled for candidates who are not able to spend unlimited amounts of their own money." ${ }^{, 35}$ The lead Democratic sponsor, Senator Richard Durbin, noted that "[w]hat we are trying to address with this amendment is to level the playing field .... That is what this amendment is all about." A Republican co-sponsor of the Millionaire Amendment, Senator Mike DeWine, described the provision as one "addressing the inequity that arises when a wealthy candidate pays for his or her campaign with personal funds." ${ }^{37}$ From these statements, this bipartisan coterie of co-sponsors did not appear concerned with the Buckley tenet regarding equality as an impermissible government objective.

\section{Reducing the appearance of corruption.}

These same supporters of the Millionaire Provision also justified the amendment as a measure to reduce corruption. Senator DeWine stressed that the provision "addresses the public perception that there is something inherently corrupt about a wealthy candidate who can use a substantial amount of his or her personal resources to win an election." ${ }^{38}$ According to DeWine, the "amendment is narrowly tailored, and closely related to [ ] concerns about [ ] perceived corruption." ${ }^{39}$ Senator Durbin likewise urged support for the amendment, arguing it would help end the perception that elections are "a system

\footnotetext{
34 Michael Coleman, Campaign Finance Bill Amended, Albuquerque J A5 (Mar 21, 2001). 2002). BCRA, HR 2356, 107th Cong, 1st Sess (Jun 28, 2001), in 148 Cong Rec S 2153 (Mar 20,

36 BCRA, 147 Cong Rec at S 2540 (Mar 20, 2001).

37 Id at $\mathrm{S} 2538$.

38 Id.

39 Id. Senator DeWine's remarks closely resemble the Supreme Court's language in its constitutional tests to determine whether a law that infringes on speech survives judicial scrutiny. See FEC v Colorado Republican Federal Campaign Committee, 533 US 431, 446 (2001) (noting contribution limits must be "closely drawn to match a sufficiently important interest") (quotation marks omitted); Nixon v Shrink Missouri Government PAC, 528 US 377, 387-88 (2000) (same). See also Part II.
} 
that is open to the highest bidder." ${ }^{40}$ On final passage of McCainFeingold the following year, Senator Domenici touted the millionaire restrictions by decrying the "perception that money rules the political process," and noted that the "large number of extremely wealthy candidates ... reinforces this perception. Many people believe that candidates are attempting to buy their way into office."

By simultaneously advancing two competing rationales - fighting the appearance of corruption and leveling the candidates' playing field - the legislative history of the Millionaire Amendment suggests either or both of these grounds motivated its sponsors. Yet, did either of these two purported rationales truly drive the Senate's consideration of what became $\S 304$ ? One could view the Senators' floor assertions with skepticism insofar as they affect incumbent officeholders' own attempts at reelection. Both the Republican and Democratic Senate campaign committees actively recruit millionaire candidates to challenge incumbents and pursue open seats. ${ }^{42}$ On the other hand, selffunded candidates endanger incumbent members of Congress in each campaign cycle.

This is not, however, to dismiss some senators' honest concerns that money controls the political process and congressional seats are for sale - and their belief that voters share those concerns. One draws this conclusion from the legislative history: Voters' elected representatives view the proliferation of wealthy, self-funded candidates as an inauspicious development.

\section{The Supreme Court AND CAMPaIgn FinANCE}

The Supreme Court's Buckley decision has controlled judicial analysis of campaign finance laws for the last thirty years. Understanding campaign finance jurisprudence requires that one first explore the basic Buckley framework, focusing on the Court's rationale for analyzing campaign contributions differently from expenditures. Aside from this distinction, two issues arise in challenges to campaign finance reform statutes similar to the Millionaire provisions: (1) whether the regulation in question results in First Amendment harm to the plaintiff and (2) whether the regulation can survive judicial scrutiny.

\section{A. Buckley v Valeo}

When the Court addressed the constitutional issues presented by the Federal Election Campaign Act, ${ }^{43}$ it faced a far-reaching law that

40 BCRA, 147 Cong Rec at S 2540 (Mar 20, 2001).

41 BCRA, 148 Cong Rec at S 2153 (Mar 20, 2002).

42 See Mercurio, Sharing the Wealth, Roll Call at 20 (cited in note 15).

43

See Federal Election Campaign Act of 1971, Pub L No 92-225, 86 Stat 3, as amended by 
restricted individual contributions to candidates ${ }^{44}$ and parties, ${ }^{45}$ and party contributions to federal candidates. ${ }^{46}$ The law also imposed disclosure requirements on candidates and parties, ${ }^{47}$ and limited overall campaign spending from personal funds. These last restrictions did not survive Buckley.

\section{Overall expenditure limits are unconstitutional.}

The Court in Buckley ruled that Congress may not limit the total amount of election campaign spending, ${ }^{48}$ since expenditure restrictions "impose direct and substantial restraints on the quantity of political speech." ${ }^{, 49}$ As such, expenditures may not be regulated as closely as other types of political money. However, voluntary limits on campaign spending do not receive the same scrutiny as government-mandated expenditure limits, and Buckley suggested voluntary limits, like those for presidential primaries, nominating conventions, and general elections, would survive a constitutional challenge..$^{\text {so }}$ The Court later affirmed a decision upholding a statute that conditioned the receipt of public funds on a candidate's decision to limit his overall expenditures. $^{\text {st }}$

\section{Contribution limits are permissible.}

In contrast, Buckley allowed the federal government to limit individuals' election-related contributions, reasoning that the government's interests in reducing corruption or the appearance of corruption "are sufficient to justify the limited effect upon First Amendment freedoms" that is caused by restricting the size of political contribu-

the Federal Election Campaign Act Amendments of 1974, Pub L No 93-443, 88 Stat 1263, codified as amended at 2 USC $\$ \S 441-56$ (2000).

44 See 2 USC $\$ 441 \mathrm{a}(\mathrm{a})(1)$ (A) (limiting individual donations to candidates to $\$ 1,000$ per election). McCain-Feingold increased this limit to $\$ 2,000$ and indexed it for inflation. See BCRA $\$ 307(a)$, (d).

45 See 2 USC $\S 441 \mathrm{a}(\mathrm{a})(1)(\mathrm{B})$ (limiting individual donations to national political parties to $\$ 20,000$ per calendar year). McCain-Feingold increased this limit to $\$ 25,000$ and indexed it for inflation. See BCRA $\S 307(\mathrm{a})$, (d).

46 See 2 USC $\$ 441$ a(d) (allowing national political parties to spend, on behalf of federal candidates, an amount tied to the voting age population (for presidential and Senate candidates), $\$ 20,000$ (for Senate candidates), or $\$ 10,000$ (for House candidates)). This section treats House candidates from states entitled to only one representative the same as Senate candidates. See id.

47 See 2 USC $\$ 434$.

48 See 424 US at 51, 54-59 (invalidating limits on independent expenditures, candidates' personal expenditures, and overall campaign spending).

49 Id at 39.

so See id at 95-96 (holding that public financing furthers "sufficiently important governmental interests and [does] not unfairly or unnecessarily burden[] the political opportunity of any party or candidate").

51 See Republican National Committee v FEC, 487 F Supp 280, 284-87 (SD NY 1980), affd, 445 US 955 (1980). 
tions to candidates and groups. ${ }^{52}$ The Court recognized the potential for intrusion on rights protected by the First Amendment, but held that regulation of campaign finance "is also critical ... if confidence in the system of representative Government is not to be eroded to a disastrous extent."

The Buckley Court ratified contribution limits by recognizing that although contribution limits do affect free speech rights, contributions are less deserving of protection than other forms of political speech. The Buckley Court considered contributions as derivative, or conduittype speech, since contributions do not become speech until they pass through a candidate's campaign. ${ }^{54}$ Contributions also represent symbolic speech by the contributor, expressing support for a preferred candidate. $^{35}$ The indirect relationship between contributions and speech permitted more stringent regulation-including dollar limitson the size of contributions. ${ }^{56}$

\section{Buckley and limits on personal expenditures.}

Given the Court's hostility toward overall expenditure limits, it is unsurprising that it also invalidated FECA's restrictions on how much an individual may spend on her own campaign. ${ }^{57}$ Restrictions on a

52 See 424 US at 29 . The Court found the government's interest in limiting quid pro quos compelling, noting "the deeply disturbing examples surfacing after the 1972 election demonstrate that the problem is not an illusory one." Id at 27.

53 Id at 27, quoting CSC v Letter Carriers, 413 US 548, 565 (1973). Letter Carriers recognized the appearance-of-corruption rationale as a legitimate interest in upholding the prohibition against federal employee involvement in political campaigns by the Hatch Act, 5 USC $\S 7324(a)(2)$ (1988). See 413 US at 565.

54 See 424 US at 21 ("[T]he transformation of contributions into political debate involves speech by someone other than the contributor.").

55 However, according to the Buckley Court, contribution limits do not significantly affect the amount of symbolic speech. See id.

56 See id at 20-23. With regard to the contributor, the limit had little effect on speech because the contributor's only expression was the "undifferentiated symbolic act of contributing." Id at 21 . With regard to the candidate, the Court found "no indication" that the contribution limitations "would have any dramatic adverse effect on the funding of campaigns" because the limits would merely require candidates to generate funds from more people. Id. The Supreme Court reaffirmed the constitutionality of contribution limits as recently as 2000 . See Nixon v Shrink Missouri Government PAC, 528 US 377, 382 (2000) (approving a $\$ 1,075$ contribution limit for state elections). See also text accompanying notes 80-88.

57 See Buckley, 424 US at 54 (invalidating limitation on a candidate's personal expenditures contained in 18 USC $\$ 608(a)$ ). The expenditure limitations, 18 USC $\$ 608(a)(1)(1970 \&$ Supp 1973), read in relevant part:

No candidate may make expenditures from his personal funds, or the personal funds of his immediate family, in connection with his campaign for nomination for election, or election, to Federal office in excess of (A) $\$ 50,000$, in the case of a candidate for the office of President or Vice President; (B) $\$ 35,000$, in the case of a candidate for the office of Senator; or (C) $\$ 25,000$, in the case of a candidate for the office of Representative, or Delegate or Resident Commissioner to the Congress. 
candidate's own expenditures must be analyzed in the same fashion as campaign expenditure limits or limits on independent expenditures. "The candidate," the Court opined, "no less than any other person, has a First Amendment right to engage in the discussion of public issues and vigorously and tirelessly to advocate his own election and the election of other candidates." ${ }^{, 58}$

Moreover, the Court found that limits on a candidate's own contributions to her campaign cannot be justified by the anti-corruption rationale that sustained contribution limits. The problem of "undisclosed and undue influence" disappears when a candidate selffinances a campaign. ${ }^{59}$ According to the Court, "the use of personal funds reduces the candidate's dependence on outside contributions and thereby counteracts the coercive pressures and attendant risks of abuse to which the Act's contribution limitations are directed." ${ }^{, 60}$ The Court invalidated FECA's personal campaign expenditures limit because "the First Amendment simply cannot tolerate [the Act's] restriction upon the freedom of a candidate to speak without legislative limit on behalf of his own candidacy.",

\section{B. First Amendment Harm}

Following Buckley's approval of contribution restrictions and invalidation of expenditure restrictions, courts reviewing campaign finance legislation have focused on two important questions. First, whether the law impairs freedom of speech or, put another way, whether there is First Amendment harm. Second, if there is such harm, whether a compelling governmental interest justifies the harm.

BCRA is not the only subsequent legislative effort to limit the impact that self-funded candidates and groups have on elections. States have passed campaign finance reform proposals that employ statutory mechanisms similar to the one created by Congress in BCRA. ${ }^{62}$ Like BCRA, these laws provide benefits to one candidate in

\footnotetext{
58 Buckley, 484 US at 52.

59 Id at 53.

60 Id.

61 Id at 54 .

62 See, for example, Ky Rev Stat Ann § 121A.030(5)(a), 121A.080(4)-(5) (Michie 1993) (releasing publicly financed candidates from spending and contribution limits and providing matching funds when their private-funded opponents exceed the spending limit); Minn Stat Ann $\$ 10$ A.25(13) (West 1997) (increasing expenditure limits for candidates targeted by independent expenditure campaigns); Minn Stat Ann § 10A.25(10)(a)(1)-(2) (West 1997) (releasing publicly funded candidates from spending limits when their non-publicly-funded opponents exceed certain limits); RI Gen Laws Ann \$ 17-25 (Lexis 2000) (lifting publicly funded candidates' spending limits when privately funded candidates exceed the publicly funded candidate's expenditure limit). See also 21-A Me Rev Stat Ann §§ 1121-28 (West 1993 \& Supp 2002) (providing public funding, matching funds commensurate to a non-participating candidate's fundraising, and subsidies for responding to independent expenditure campaigns).
} 
response to her opponent's campaign spending or that of an outside group. Different courts have come to opposite conclusions on whether singling out selected candidates for benefits in response to their opponent's decision to exercise a constitutional right to spend campaign funds infringes the opponent's free speech rights.

1. Benefiting candidates chills political speech.

In 1994, Minnesota's election law provided partial public subsidies to campaigns that agreed to limit campaign expenditures voluntarily. ${ }^{63}$ In addition, the law increased spending limits for these publicly funded candidates and provided subsidies to them to respond to an independent expenditure campaign ${ }^{64}$ run against them. ${ }^{65}$

Minnesota's law required groups or individuals seeking to conduct independent expenditure campaigns to notify the state election board and the candidates in the race of their intentions. The candidate facing an independent expenditure campaign may exceed the voluntary spending limit, up to the amount spent by the independent campaign. Also, a candidate facing a hostile independent expenditure campaign may ${ }^{60}$ receive additional public subsidies in the amount of half the level of the independent expenditure. ${ }^{67}$

In 1994, state political action committees, candidates, and contributors challenged Minnesota's law in Day $v$ Holahan. ${ }^{68}$ The Day plaintiffs alleged that the law restricted their First Amendment rights to make independent expenditures. The district court upheld these provisions, ${ }^{69}$ but the Eighth Circuit reversed. The Eighth Circuit held, "To the extent that a candidate's campaign is enhanced by the operation of the statute, the political speech of the individual or group who made the independent expenditure 'against' her (or in favor of her opponent) is impaired." In the court's view, any group considering making an independent expenditure would likely consider whether its decision would cause its opponent to enjoy higher spending limits and greater public financing. The knowledge that a targeted candidate

\footnotetext{
63 See Day v Hayes, 863 F Supp 940, 942-43 (D Minn 1994), affd in part, revd in part as Day $v$ Holahan, 34 F3d 1356, 1366 (8th Cir 1994).

64 An independent expenditure campaign is one paid for by an individual or group not authorized nor coordinated with any particular campaign or candidate in the race. See BCRA $\$ 211$.

65 See Hayes, 863 F Supp at $945-46$.

66 Only those candidates who have qualified for public subsidies and have raised twice the minimum matching funds are eligible for subsidies in response to independent expenditures. See Minn Stat § 10A.25(13)(c) (Supp 1993).

67 See id.

6834 F3d 1356, 1359 (8th Cir 1994).

69 See Hayes, 863 F Supp at 957-58.

70 Day, 34 F3d at 1360.
} 
would benefit could discourage an independent group from speaking in the first place." In fact, the court stated that "[ $t]$ his 'self-censorship' that has occurred even before the state implements the statute's mandates is no less a burden on speech that is susceptible to constitutional challenge than is direct government censorship.",

2. Benefits to candidates enhances, not chills, political speech.

Two years after Day, in Rosenstiel $v$ Rodriguez, ${ }^{73}$ the Eighth Circuit considered another legal challenge to Minnesota's campaign law. Yet, in contrast to its previous decision, its opinion in this case suggests that some benefits to candidates who agree to limit their spending do not harm their opponent's ability to exercise their First Amendment rights.

The law challenged in Rosenstiel contained numerous provisions designed to encourage political candidates to participate in the state's campaign finance system. In exchange for voluntary candidate spending limits, the state provided campaign subsidies of up to half the spending limit. The law also waived a participating candidate's spending limit if a non-participating opponent raised or spent over a certain amount. Finally, donors to participating candidates-but not nonparticipating candidates-received a partial tax refund for contributions, which encouraged donations. ${ }^{74}$

The Rosenstiel plaintiffs argued that the waivable spending limit and tax break provisions coerced candidates into a publicly subsidized system of campaign finance. ${ }^{75}$ This coercion, the plaintiffs contended, offended the First Amendment. The court disagreed. It determined that the waivable spending limit does not coerce candidates because it allows the non-participating candidate to control her participating opponent's funding. ${ }^{76}$ The candidate who opts out of the system may still raise (and spend) as much money as the candidate pleases. Once the non-participating candidate exceeds the participating candidate's spending limit, she waives her opponent's spending limit. The level of her adversary's spending rests entirely in the hands of the nonparticipating candidate." The court also upheld the tax break incentive as not infringing on First Amendment rights, calling the tax refund

71 See id (finding that the law "chills the free exercise of that protected speech").

72 Id.

73101 F3d 1544 (8th Cir 1996).

74 See id at $1546-47$.

75 See id at 1549.

76 See id at 1551 .

77 See id ("[The statute] permits the nonparticipating candidate to control whether and when the participating opponent will be freed from the limits. Thus, in a sense, the amendment works in favor of, rather than to the detriment of, the nonparticipating candidate."). 
"simply an additional public subsidy provided to participating candidates." ",

3. Reconciling the dilemma: Incentives to limit spending do not chill speech.

So which Eighth Circuit panel is correct? One easy argument is that both are right. A few key elements distinguish Day and Rosenstiel and can account for their seemingly contradictory conclusions. Day invalidated public subsidies to a candidate in response to being targeted by an independent expenditure campaign. Rosenstiel approved of public subsidies to a candidate in response to her opponent's campaign spending. In the latter situation, the non-participating candidate can control the consequence of exceeding a known threshold. In the former, by definition, the candidate cannot, since she does not authorize nor direct an independent expenditure campaign.

But the distinction between independent and candidate expenditures forms a slender reed on which to rest these contrary decisions. The First Amendment's free speech clause protects both independent and candidate expenditures. Recall that Buckley makes no distinction between the two; the Court there struck down campaign spending limits and independent expenditure limits alike for encroaching on core areas of free speech. The harms alleged by the plaintiffs-diminished exercise of free speech-do not turn on whether the candidate or an independent group speaks.

Perhaps the different type of benefits conferred on candidates under the different laws helps distinguish the outcomes in these two cases. Day invalidated provisions that both increased public subsidies to a candidate targeted by an independent expenditure campaign, and increased the targeted candidate's expenditure limits. Rosenstiel validated tax benefits to encourage additional donations to participating candidates. Regardless, this alone cannot account for the contrary court decisions: Both conferred benefits on participating candidates and denied them to non-participants.

The two decisions still collide on the critical issue: Whether increasing expenditure limits for one candidate violates the free speech rights of a potential speaker. In Part III, I argue that Rosenstiel contains the better reasoning: The mere provision of benefits to one candidate does not chill the speech of her opponent.

78 Id. See also id at 1555 n 11 (rejecting the argument that allowing some candidates' donors to receive tax refunds "puts the state's imprimatur on publicly funded candidates"). 


\section{Judicial Scrutiny and Governmental Interests}

Before examining the Millionaire Provision against this backdrop, one Supreme Court decision illuminated both what standard of review courts should apply to contribution limits and what governmental interests satisfy the government's burden. Since campaign finance restrictions touch on core First Amendment concerns, courts have usually held that campaign finance laws must meet strict scrutiny. ${ }^{79}$

However, the Supreme Court's decision in Nixon v Shrink Missouri Government PAC, ${ }^{\text {so }}$ decided after Day and Rosenstiel, clarified that contribution limits receive a less exacting review than strict scrutiny. The plaintiffs in Shrink Missouri challenged Missouri's inflationadjusted state contribution limit of $\$ 1,075$. $^{81}$ They argued that the state had not presented sufficient evidence that the law met the state's legitimate interests, since it had neither shown empirical evidence of corruption nor demonstrated the public's belief in the appearance of corruption. ${ }^{82}$ The Eighth Circuit agreed and struck down the law, ${ }^{83}$ but the Supreme Court reversed. ${ }^{84}$

Justice Souter's majority opinion reiterated that contribution restrictions "require less compelling justification than restrictions on independent spending." ${ }^{, 55}$ Rather, the crucial question for the Court was "whether there was any showing that the limits were so low as to impede the ability of candidates to 'amas[s] the resources necessary for effective advocacy.", 86

Importantly, the Shrink Missouri Court also noted its institutional unwillingness to "second-guess a legislative determination as to the need for prophylactic measures where corruption is the evil feared." ${ }^{87}$

79 See, for example, Buckley, 424 US at 44-45 (finding expenditure limits must satisfy "exacting scrutiny applicable to limitation on core First Amendment rights of political expression"). Commentators and the Court, in subsequent decisions, have faulted Buckley's vagueness in establishing the proper level of review for different campaign restrictions. See, for example, Shrink Missouri, 528 US at 386 ("Precision about the relative rigor of the standard to review contribution limits was not a pretense of the Buckley per curiam opinion."); Richard Briffault, Nixon v. Shrink Missouri Government PAC: The Beginning of the End of the Buckley Era?,85 Minn L Rev 1729, 1745 (2002) ("Buckley had been maddeningly imprecise on this question.").

80528 US 377 (2000).

81 See id at 382-85. In current dollars, the Missouri contribution limit permitted donations much smaller than those approved in Buckley's 1976 decision.

82 See id at 384-85.

83 See Shrink Missouri Government PAC v Adams, 161 F3d 519 (8th Cir 1998).

84 See Shrink Missouri, 528 US at 385.

85 Id at 387 (quotation marks omitted). See also Briffault, 85 Minn L Rev at 1729-30 (cited in note 79 ).

86 Shrink Missouri, 528 US at 397.

87 Id at 391 n 5, citing FEC v National Right to Work Committee, 459 US 197, 210 (1982). The Shrink Missouri majority also accepted the legislature's finding of perceived corruption, which the state supported with several news articles regarding political scandals, the results of a voter referendum on reform, and a legislator's affidavit attesting to the public's perception of 
The Court abjures this deference, however, when examining laws that create a "risk [of] such constitutional evils as, say, permitting incumbents to insulate themselves from effective electoral challenge."

The decisions in Day (1994) and Rosenstiel (1996) predate Shrink Missouri. Day shows that courts examine purported state interests seriously. The court, viewing the state's justification as pretextual, invalidated Minnesota's law providing matching funds to independent expenditure campaign targets. Even had the Day court shown the level of deference toward the state's assertion of its interest that the Supreme Court showed in Shrink Missouri, it is doubtful the outcome would have changed. The court held that the law challenged would not have met even the most cursory review.

The Rosenstiel court argued that encouraging participation in public funding programs constitutes a compelling state interest, when candidate participation helps reduce corruption or its appearance, including through reducing the time and energy candidates exert raising money. This conclusion fits with the post-Buckley trend of expanding the range of corruption-related interests that can justify state campaign laws. The Court has recognized that corruption of the electoral process can result from the "corrosive and distorting effects of immense aggregations of wealth," which "have little or no correlation to the public's support for ... political ideas.", Although the Court confined its decision to those effects caused by corporate aggregations of wealth, it may be logically extended to personal wealth accumulation. So, the state's interest in reducing corruption may include types of corruption apart from the quid pro quo corruption recognized in Buckley, ${ }^{94}$ and states may pursue that goal by encouraging participa-

corruption. The sufficiency of this quantum of evidence was "not [ ] a close call" according to the Court. Id at 393.

88 Shrink Missouri, 528 US at $402-04$.

89 The state attempted to justify the provisions by insisting that they were necessary to encourage candidate participation in the state's partial public financing system. The court reasoned that the new provisions could not be "necessary" because, even prior to the regulation, candidate participation in the state's partial subsidies system reached 97 percent. See 34 F3d at 1361 ("One hardly could be faulted for concluding that this 'compelling' state interest was contrived for purposes of this litigation.").

90 See id at 1362 ("The statute's burden on First Amendment rights does not satisfy strict, intermediate, or even the most cursory scrutiny.").

91 See $101 \mathrm{F3d}$ at 1553.

92 See, for example, Austin v Michigan Chamber of Commerce, 494 US 652 (1990) (upholding state ban on corporate independent expenditures); Julian N. Eule, Promoting Speaker Diversity: Austin and Metro Broadcasting, $1990 \mathrm{~S} \mathrm{Ct} \mathrm{Rev} \mathrm{105,} 106$ ("The concept that government may tone down or amplify particular voices in order to promote speaker diversity is no longer a stranger to the First Amendment.").

93 Austin, 494 US at 660.

94 See 424 US at 27-28. 
tion in public finance systems that reduce corruption by reducing the time and energy candidates spend amassing funds.

With this background of Buckley and subsequent court decisions reviewing state campaign finance laws, the stage is set to examine BCRA's Millionaire Provision.

\section{The First AMENDMENT Challenge to the MILLIONAIRE PROVISION}

The Millionaire Provision has been attacked on First Amendment and Equal Protection grounds in an ongoing lawsuit seeking to invalidate various provisions of BCRA. ${ }^{.5}$ In an argument similar to that relied upon by the Eighth Circuit in Day, the plaintiffs contend that the Millionaire Provision burdens speech by benefiting a wealthy candidate's opponent. This Part argues that the Millionaire Provision inflicts slight, if any, First Amendment harm on wealthy candidates. Even if there is a First Amendment harm, whatever free speech infringement exists by virtue of the raised contribution limits may be justified by achieving the government's interest in reducing corruption.

\section{A. No Likely Burdens on Free Speech}

In fashioning the Millionaire Provision, lawmakers sought to avoid Buckley's strict prohibition on spending limits. In order to find that BCRA impermissibly burdens speech, a court must hold that releasing others from contribution limits constitutes a restriction on the speaker who is not released from those limits. As seen above, the first federal appeals court to consider this question, the Eighth Circuit, has reached two different answers. ${ }^{96}$ Given these varying treatments of First Amendment challenges to campaign finance laws, the next step requires understanding why the Eighth Circuit's Rosenstiel decision contains the better reasoning and applies with more force to BCRA's Millionaire Provision than its conclusion in Day, that any attempt to facilitate the speech of one candidate impairs the rights of the opponent. ${ }^{97}$ $10)$.

95 See Second Amended Complaint, McConnell v FEC, No 02-0582 (RJL) (cited in note

96 Compare Day, 34 F3d 1356 (invalidating subsidies to publicly funded candidates targeted by independent expenditure campaigns), with Rosenstiel, 101 F3d 1544 (upholding subsidies to publicly funded candidates, waivable spending limits, and tax refunds to their donors).

97 See Day, 34 F3d at 1360 ("To the extent that a candidate's campaign is enhanced by the operation of the statute, the political speech of the individual or group who made the independent expenditure 'against' her (or in favor of her opponent) is impaired."). 
1. Responsive speech augments the First Amendment.

First, any speech by a wealthy candidate's opponent, funded by relaxed contribution limits, would necessarily occur after the selffunded candidate has "spoken" (that is, spent the money) or announced her intention to do so. As such, the non-wealthy candidate engages in responsive speech, following the initial expressive activity by the wealthy candidate.

The First Circuit's 2000 decision in Daggett $v$ Commission on Governmental Ethics and Election Practices supports this idea. The Daggett court reviewed Maine's full, voluntary, publicly-funded election system, which provided participating candidates both a dollar-fordollar match of their non-participating opponent's fundraising total, and matching funds, like in Day, to respond to independent expenditure campaigns.

The Daggett court did not view the dispute as a zero-sum game where the speech funded by the government subsidies cancelled out the speech from the independent expenditures that triggered the state subsidies in the first place. Instead, the court reasoned that independent spenders and the candidates they support "have no right to speak free from response" and that such a provision increased, rather than infringed, political speech. ${ }^{101}$ In so concluding, the First Circuit rejected Day: "We cannot adopt the logic of Day, which equates responsive speech with an impairment to the initial speaker." ${ }^{\text {,102 }}$ A similar argument applies to BCRA's Millionaire Provision: The fact that a wealthy candidate's speech increases his opponent's ability to raise funds does not impair the speech of the wealthy candidate.

The Daggett court did not address the concern that motivated the Eighth Circuit in Day: that the knowledge that one's opponent will benefit from a wealthy candidate's spending will inhibit the selffunded candidate from speaking in the first place. Three reasons, however, suggest that the Day court's fear would not materialize with wealthy candidates. First, in a race between a wealthy and a nonwealthy candidate, the self-funded aspirant will almost always be able to outspend her opponent. Thus, the wealthy candidate will still benefit from her ability to spend her own money. Additionally, aside from her ability to spend more, the wealthy candidate benefits from the

98 The Millionaire Provision increases contribution limits after an opponent announces her intention to spend a certain amount of personal funds. This is to deter self-funded candidates from dumping a large amount of personal funds in the final days of a campaign, effectively undermining the provision.

99205 F3d 445 (1st Cir 2000).

100 See id at $450-51$.

101 See id at 464.

102 Id at 465. 
ease with which she obtains her campaign funds. After all, her nonwealthy opponent must spend a significant amount of time raising funds. The wealthy candidate need only write a check. ${ }^{103}$ The task of raising and spending campaign funds will remain more daunting for the non-self-funded candidate. The wealthy candidate always has more options than the non-wealthy one, since a self-funded candidate can always choose to raise funds through limited individual contributions. ${ }^{104}$

Second, the wealthy candidate retains control over how much her opponent may permissibly raise. By strategically limiting her own expenditures, the wealthy candidate may choose whether to benefit her opponent with raised contribution levels, and if so, at what increased contribution level. Courts that have evaluated the legitimacy of state incentives to participate in campaign finance systems have focused on the notion of coercion. ${ }^{105}$ Statutory provisions that leave a candidate a choice as to whether to participate are viewed much more favorably than those that coerce candidates into joining the program through draconian measures.

Third, Day's conclusion regarding the "chilling" effect proves too much. Day invalidated publicly financed subsidies given to a candidate in response to independent expenditure campaigns against that candidate or in support of her opponent. The court reasoned that the plaintiffs were harmed by the knowledge that their opponents would benefit, via public subsidies, from their expenditures - and that this harm discouraged them from making those expenditures in the first place.

103 The First Circuit described the argument by the appellants, who sought to invalidate candidate subsidies in response to an opponent's or an independent's expenditure as "a claim of a First Amendment right to outraise and outspend an opponent." Id at 464.

104 Consider the decision in Republican National Committee v FEC, 487 F Supp 280, 285 (SD NY 1980), affd 445 US 955 (1980), in the context of the presidential public funding system:

[A] candidate with an additional funding alternative which he or she would not otherwise have ... does not deprive the candidate of other methods of funding which may be thought to provide greater or more effective exercise of rights of communication or association than would public funding. Since the candidate remains free to choose between funding alternatives, he or she will opt for public funding only if, in the candidate's view, it will enhance the candidate's powers of communication and association.

105 See Rosenstiel, $101 \mathrm{~F} 3 \mathrm{~d}$ at 1552 ("This scheme presents candidates with an additional, optional campaign funding choice, the participation in which is voluntary .... Given this ... the State's scheme promotes, rather than detracts from, cherished First Amendment values."); Vote Choice v DiStefano, 4 F3d 36, 38 (1st Cir 1993) ("[V]oluntariness has proven to be an important factor in judicial ratification of government-sponsored campaign financing schemes."); Wilkinson $v$ Jones, 876 F Supp 916, 927 (WD Ky 1995) ("[T]he determination whether to engage in the triggering activity ... is within the privately-financed candidate's complete control."). For the importance of voluntariness in federal spending limits, see, for example, Buckley, 424 US at 95 ("[A]cceptance of public financing entails voluntary acceptance of an expenditure ceiling."); $R e$ publican National Committee, 487 F Supp at 285 (stressing the importance that "the candidate remains free to choose between funding alternatives"). 
This principle, applied to other situations, proves unwieldy. If this logic holds, any campaign finance incentives in any system could create an arguable First Amendment harm. For instance, it is difficult to see how the federal government's system of partial subsidies in presidential primaries and full public funding in presidential general elections would survive. ${ }^{106}$ The federal subsidies and full public funding benefit only those candidates who cannot afford to self-fund. ${ }^{107}$ Thus, a wealthy candidate would be discouraged from spending her own funds because, by doing so, she would become ineligible for public funds. Under the Day rationale, therefore, the wealthy candidate suffers First Amendment harm. But it cannot be that the federal funding system harms wealthy candidates who opt out and choose to fund their own campaigns. ${ }^{108}$ They retain - and use-another avenue for funding their campaign: self-funding. Furthermore, the government does not have to treat candidates equally in encouraging participation in its campaign finance systems. As the First Circuit explained in Daggett, "a voluntary campaign finance scheme must rely on incentives for participation, which, by definition, means structuring the scheme so that participation is usually the rational choice." ${ }^{\text {,109 }}$ Without providing incentives, the state could never encourage voluntary compliance with a program designed to reduce corruption or its appearance. ${ }^{110}$

\section{Varying contribution limits do not restrict speech.}

BCRA's Millionaire Provision raises the possibility of two candidates, in the same race, raising different-sized contributions. But the fact that two opponents must raise private funds, if they raise funds at all, subject to different contribution limits would not create a First Amendment problem in itself. States have encouraged candidates to

106 In primaries, federal candidates for President may receive matching funds for their privately raised donations in exchange for agreeing to limit their expenditures. In presidential general elections, candidates receive full public funding in exchange for the same forbearance. In addition, the candidates agree not to raise private funds for the general election. See text accompanying note 51 .

107 In 1979, opponents of the presidential system argued that the presidential system unconstitutionally coerced all candidates into participating and infringed their First Amendment rights by barring anyone from contributing to or making expenditures on behalf of publicly funded presidential candidates. The district court rejected both arguments, and the Supreme Court affirmed. See Republican National Committee, 487 F Supp at 285-86.

108 See Buckley, 424 US at 92-93 ("[The presidential public funding system] is a congressional effort, not to abridge, restrict, or censor speech, but rather to use public money to facilitate and enlarge public discussion and participation in the electoral process .... [It] furthers, not abridges, pertinent First Amendment values."). The Millionaire Provision employs federal contribution limits, instead of public funding, to achieve this goal.

$109205 \mathrm{~F} 3 \mathrm{~d}$ at 470 (quotation marks omitted).

110 The state can even express a preference for smaller donations over larger ones. See Buckley, 424 US at 107 ("The thrust of the [presidential primary matching] legislation is to reduce financial barriers and to enhance the importance of smaller contributions."). 
limit their spending by making fundraising easier, not only by providing public subsidies, but by increasing their donation limits.

The First Circuit, in Vote Choice, Inc v DiStefano, ${ }^{11}$ approved Rhode Island's campaign finance system of differing contribution limits. ${ }^{112}$ Rhode Island maintained a $\$ 1,000$ contribution limit for all candidates, but doubled it for candidates who accepted public financing and agreed to limit their spending to a statutorily defined amount. The court held that incentives to accept public funding did not penalize those who opted out of the system: "[T]he contribution cap gap ... neither penalizes certain classes of office-seekers nor coerces candidates into surrendering their first amendment rights." ${ }^{\prime 13}$

The Vote Choice court did issue a caveat by noting that, at some point, the state's incentives to participate in its public finance system could become so lucrative that they deny candidates the freedom to choose between funding methods. When "regulatory incentives stray beyond the pale, creating disparities so profound that they become impermissibly coercive," the court expressed its willingness to invalidate those elements of a campaign finance system. ${ }^{1.4}$

Disparate contribution limits do not necessarily create a constitutional infirmity. Under the Vote Choice view, the coerciveness of a campaign finance system's carrots and sticks determines whether it creates a First Amendment problem. ${ }^{115}$ The Millionaire Provision should likewise avoid this constitutional problem, as long as, in practice, the incentives do not become so overbearing that a candidate would rather run against a millionaire than run as a millionaire. If a wealthy candidate can still find that funding her own campaign creates a net advantage, then it is difficult to classify the increased contribution limit for her opponent as "coercive." that increased contribution limits could be coercive applies with less force to wealthy candidates. In a race between two candidates of relatively equal means, every potential advantage can mean the difference between winning and losing. ${ }^{177}$ The manifest advantages enjoyed by

1114 F3d 26.

112 See id at 37,40 .

113 Id at 39.

114 See id at 38.

115 One might argue that "coercive" is synonymous with "effective" and the law could thus work too well. But an alternative exists. The Millionaire Provision might achieve its goal of reducing the appearance of corruption in a way that does not impose limits on candidate speech.

116 To extend the analogy, just as a state candidate could voluntarily limit her spending in exchange for public funding and an easier fundraising task, the wealthy candidate can voluntarily limit her spending in exchange for imposing lower (that is, the original) contribution limits on her opponent.

117 In a race between candidates of different means, say, an incumbent and a wealthy challenger, both candidates might have access to equal funds. The Millionaire Provision accounts for this, by capping fundraising under elevated limits to the level of personal spending by one's op- 
wealthy candidates suggest they would be less susceptible to a campaign finance system's incentives to limit spending.

This Comment has argued that the Millionaire Provision does not infringe freedom of speech for three reasons. First, BCRA does not limit a wealthy opponent's speech; it increases the ability of his opponent to speak without limiting the speech of the wealthy candidate. Second, even if the increased contribution limits could, in some circumstances, create First Amendment harm, the federal courts have only recognized such harm when it is "coercive." These cases make clear that BCRA is not coercive. Finally, even if the variable contribution limits burden a wealthy candidate's First Amendment rights, the Millionaire Provision should still be sustained because it meets the judicial scrutiny required by Buckley and subsequent Supreme Court decisions.

\section{B. Raising Contribution Limits May Meet Judicial Scrutiny}

Buckley held that campaign finance laws may burden speech to reduce corruption or the appearance of corruption. The federal courts have held that state incentives to participate in state campaign finance systems may be justified on the same rationale: Participation in the campaign finance systems reduces corruption through voluntary spending limits and partial public funding.

At first blush, these cases seem inapposite. Congress could not be attempting to encourage compliance with a system of partial or total public funding and voluntary spending limits: There is no such system for congressional candidates. Rather, the Millionaire Provision resembles an incumbent protection scheme or an attempt to equalize candidate competitiveness, two impermissible state interests. ${ }^{118}$ However, Congress has in effect created a system of voluntary spending limits by establishing statutory thresholds for spending personal funds. The Millionaire Provision limits spending personal funds and creates a voluntary cap at twice the statutory threshold, at which point the opponent's contribution limits begin to rise. Overall federal campaign spending remains uncapped outside the presidential election.

BCRA's congressional supporters argued that reducing the amount of money in the political system-and wealthy candidates' ability to "buy" a seat in Congress-reduces precisely the type of corruption that voters fear most: that money matters more than ideas in electoral contests. ${ }^{19}$ Congress may decide that its legislative goals re-

ponent, and by factoring in each candidate's success in accumulating campaign funds. See Parts I.B.2 and I.B.3.

118 See, for example, Shrink Missouri, 528 US at 402; Buckley, 424 US at 48-49.

119 See Part I.C. 
quire encouraging voluntary personal spending limits and "need not be completely neutral" in encouraging wealthy candidates to comply.

Furthermore, BCRA is narrowly tailored to achieve this purpose of preventing corruption without becoming unnecessarily restrictive. Several aspects of the Millionaire Provision in particular demonstrate Congress's attention to detail in crafting it.

First, the provision increases contribution limits incrementally, graduated to the wealthy candidate's own spending. ${ }^{121}$ A candidate's contribution limits increase to a certain level and no higher, regardless of the self-funded candidate's spending.

Second, the provision benefits a non-wealthy candidate only insofar as she does not raise funds beyond her wealthy opponent's personal spending level. ${ }^{122}$ Both the House and Senate measures cap the fundraising accomplished under looser restrictions to the level of the opponent's self-funding.

Third, the formula for determining who benefits from the Millionaire Provision factors in the personal spending of both candidates, to avoid flooding a race with more funds-both money raised under higher limits and from candidates' own funds. ${ }^{123}$ Every dollar of personal funds spent by one opponent counts against the threshold formula for determining the opponent's raised contribution limits.

Finally, the Millionaire Provision takes into account each candidate's available funds raised in anticipation of a race, to help rebut the charge that the new law helps further entrench incumbent members of Congress. ${ }^{124} \mathrm{By}$ accounting for "available funds," the law avoids discriminating against challengers whose only opportunity to win could hinge on personal spending because of the war chest amassed by the incumbent.

These provisions answer critics' charges that the increase in contribution limits gives lie to Congress's assertion that the limits are necessary to reduce corruption. Given the judicial deference typically shown to legislative determinations regarding corruption in politics, Congress may determine that wealthy candidate spending poses a greater "corruption" threat, and one that has not yet been addressed."

120 Vote Choice, 4 F3d at 39-40.

121 See Part I.A.

122 See Part I.B.3.

123 See Part I.B.2.

124 See id.

125 See, for example, Shrink Missouri, 528 US at 391-92 \& n 5.

126 Buckley itself found Congress uniquely qualified to make other determinations regarding the appropriate, corruption-reducing contribution level. Regarding the original congressional decision to limit individual contributions to $\$ 1,000$, the Court noted, “Congress' failure to engage in such fine tuning does not invalidate the legislation.... [I]f it is satisfied that some limit on contributions is necessary, a court has no scalpel to probe, whether, say, a $\$ 2,000$ ceiling might not 
In this sense, Congress is balancing two different risks of corruption. It is increasing the chance of quid pro quo corruption through increased individual contribution limits for one candidate, while decreasing the risk of the appearance of corruption through the phenomenon of wealthy individuals "buying" congressional seats that are "for sale."

\section{CONCLUSION}

The BCRA provisions dealing with wealthy, free-spending candidates can survive judicial scrutiny, since they avoid direct restrictions on a candidate's spending and leave the candidate's First Amendment rights unimpaired. The state's interests in reducing the appearance of corruption justify whatever harm to free speech might arise, judged under the standard of scrutiny the Supreme Court applies to contribution restrictions. This Comment analyzed only the potential for a constitutional challenge based on the wealthy candidate's First Amendment rights. Other avenues may prove more treacherous for the Millionaire Provision, from donors' or political parties' free speech and association interests ${ }^{127}$ to equal protection claims. ${ }^{128}$ These possibilities lie beyond the scope of this Comment.

Congress has created a system of incentives it says will increase the amount of free speech and widen the pool of candidates beyond the independently wealthy. Congress has sought a constitutional way to address campaigns by wealthy self-funded candidates for more than the last quarter-century. The Millionaire Provision does this without burdening free speech. The law may in fact enhance speech, and simultaneously enhance the faith of the electorate that public office cannot be bought by the highest bidder. Twenty-eight years ago, the Supreme Court found this aspiration "critical ... if confidence in the system of representative Government is not to be eroded to a disastrous extent."

serve as well as $\$ 1,000, " 424$ US at 30 (quotation marks omitted).

127 See BCRA $\$ 304$ (permitting party donations over the normal limit when an opponent's personal funds amount reaches ten times the threshold limit).

128 Buckley considered and rejected a similar claim. See 424 US at 30-35. The Republican National Committee, as a plaintiff in the consolidated McConnell v FEC, made this argument and urged the court to extend the benefits of unlimited party spending and higher contribution limits to all candidates, rather than invalidate the provisions. See Consolidated Brief for Plaintiffs in Support of Motion for Judgment, McConnell v FEC, No 02-0582, RNC Brief, Title III at *7375 (D DC filed Nov 6, 2002), online at http://www.law.stanford.edu/library/campaignfinance/ mcconnell/SFX20B.pdf (visited May 8, 2003).

129 Buckley, 424 US at 27 (quotation marks omitted). 
